\title{
Analysis for Science Librarians of the 2014 Nobel Prize in Physiology or Medicine: The Life and Work of John O'Keefe, Edvard Moser, and May-Britt Moser
}

\author{
Neyda V. Gilman \\ Colorado State University, Fort Collins, CO
}

\begin{abstract}
Navigation and awareness of space is a complicated cognitive process that requires sensory input and calculation, as well as spatial memory. The 2014 Nobel Laureates in Physiology or Medicine, John O'Keefe, Edvard Moser, and May-Britt Moser, have worked to explain how an environmental map forms and is used in the brain (Nobelprize.org 2014b). O'Keefe discovered place cells that allow the brain to learn and remember specific locations. The Mosers added the second part of the "positioning system in the brain" with their discovery of grid cells, which provide the brain with a navigational coordinate system (Nobelprize.org 2014b).
\end{abstract}

\section{Introduction}

Alfred Nobel dictated in his will that his millions were to be used to create the Nobel Foundation in order to fund Nobel Prizes, the first of which was awarded in 1901 (Nobelprize.org 2014g). The Prize for Physiology or Medicine is given to those who are found to have made a major discovery that changes scientific thinking and benefits mankind. Between 1901 and 1953 there were over 5,000 individuals nominated for the Physiology or Medicine prize, less than seventy of which eventually became Laureates. For the 2014 Prize alone, 263 scientists were nominated (Nobelprize.org 2014h). The prize is not meant to honor those who are seen as leaders in the scientific community or those who have made many achievements over their lifetime. While these are often qualities of Laureates, the Prize itself is awarded only for beneficial discoveries that change scientific thinking and understanding. These discoveries are few, and it is often decades before their true impacts are realized and recognized. On October 6, 2014, John O'Keefe, Edvard Moser, and May-Britt Moser were awarded the $105^{\text {th }}$ Nobel Prize in Physiology or Medicine for their groundbreaking work leading to the discovery of cells in the brain that provide a sense of navigation and place (Nobelprize.org 2014b).

John O'Keefe made the initial discovery of place cells in the hippocampus during the late 1960s and early 1970s. His findings were first published in his 1971 article "The Hippocampus as a Spatial Map-Preliminary Evidence From Unit Activity in the Freely-Moving Rat" (O'Keefe and Dostrovsky 1971). It was this discovery, and his subsequent research, that earned O'Keefe half of the 2014 Nobel Prize in Physiology or Medicine. More than 20 years after his pivotal discovery, O'Keefe supervised May-Britt and Edvard Moser during their postdoctoral fellowships in his lab. The young couple went on to discover grid cells, the second part of the brain's "inner GPS," earning them the other half of the Prize. Their discovery was published in the 2005 article "Microstructure of a Spatial Map in the Entorhinal Cortex" (Hafting et al. 2005). These discoveries have set the stage for further research and understanding of the brain.

\section{The Science}

The medial temporal lobe, including the hippocampus, amygdala, and entorhinal cortex, is the brain's memory center (Squire and Zola-Morgan 1991) (see Figure 1). The term hippocampus comes from the combination of the Greek words for horse (hippos) and caterpillar (kampe) and was first used in Greek literature when referring to seahorses. In 1587 the anatomist Arantus was studying the human brain and 
used the word to describe a previously unnamed structure that he thought resembled the shape of a seahorse. Although there is some debate about what exact region of the brain Arantus was describing when he applied the term, it has come to be the name used today (Walther 2002).

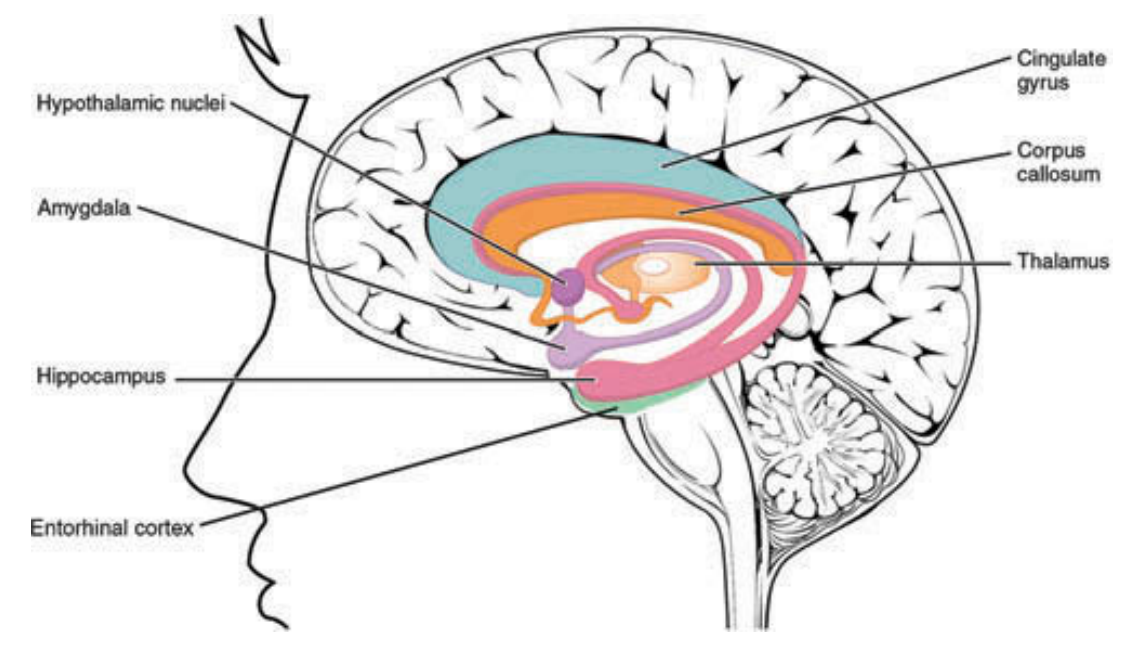

FIGURE 1 Image showing the hippocampus, amygdala, and entorhinal cortex (Adapted from OpenStax College, 2013, CC-BY 3.0 license.)

The hippocampal region was studied extensively in the 1950s and 1960s (Burgess, Maguire, and O'Keefe 2002; Walther 2002). Probably the most defining study on the hippocampus is that by Scoville and Milner in 1957. In this study, experimental operations excising part of the hippocampus were performed on three patients. Two of the patients suffered from mental disorders and one suffered from epilepsy. All three patients recovered from the surgery, improved though with severe memory disturbances. The two patients with mental disorders appeared to have better temperament but later showed memory loss. The epileptic patient, H. M., recovered from surgery with less-incapacitating seizures but showed the most immediate signs of memory problems (Scoville and Milner 1957). The case of H. M. is often regarded as the first study showing the role of the hippocampus in the memory process. Even though the hippocampus and surrounding features had been studied for centuries, an article by Vanderwolf (1969) indicated that its function was still not very well known. O'Keefe and Dostrovsky (1971) furthered Vanderwolf's research on the hippocampus, publishing his research and arguing that the hippocampus serves as a "spatial map" and discussing the cells that make up the map. These cells were named place cells in a later article by O'Keefe er al. (1975) and were more thoroughly described in O'Keefe's (1976) article "Place Units in the Hippocampus of the Freely-Moving Rat."

O'Keefe's work built upon previous research done on rats and navigation. Tolman (1948) discussed navigation and a way of thinking that imagined rats in a maze building a "field map" of their environment in order to learn how to quickly navigate to food. O'Keefe and Dostrovsky (1971) were able to go beyond previous research, including that of Tolman and Vanderwolf, by attaching electrodes onto the skulls of rats, which allowed them to visualize and record brain activity. They saw that certain cells fired when the rat was in a certain space and position but then stopped firing as soon as the rat moved (see Figure 2 ). The firing in individual cells seemed to be in response to specific locations and demonstrated that place cells work together to form a spatial map. 


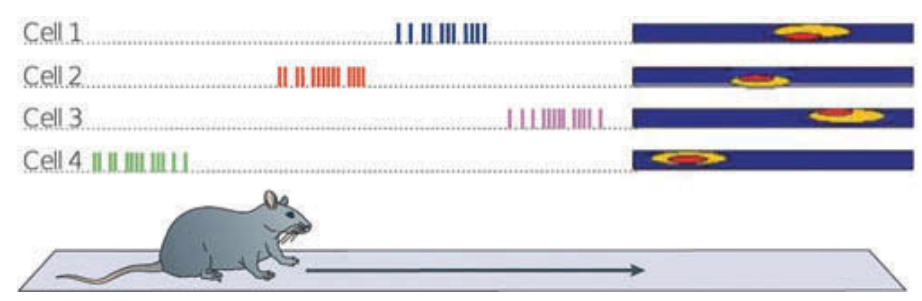

FIGURE 2 Electrodes inserted into a rat's hippocampus show individual cells firing when the rat is in a specific place. (Adapted by permission from Macmillan Publishers Ltd: Nature Reviews Neuroscience, "NMDA receptors, place cells and hippocampal spatial memory," copyright 2004.)

Since the discovery of rodent place cells, scientists have continued to study these cells and explore whether there are similar sets of cells in the human brain. Ekstrom et al. (2003) recorded the firing of neurons while humans explored a virtual town. They found hippocampal cells that responded to place, view, goal, and combinations of the three, suggesting that humans have analogous cells to rodent place cells. A couple of years after Ekstrom, the Mosers discovered the second half of the brain's navigational system: grid cells (Hafting et al. 2005).

Edvard and May-Britt Moser learned O'Keefe's techniques for monitoring rat brain cell activity while working in his laboratory in 1996. When they returned to their own lab, they used these techniques and continued studying the hippocampal formation in regards to space and location (Nobelprize.org 2014d). When experimental lesions on the hippocampus did not result in the expected loss of navigation, the Mosers looked at other features, including the entorhinal cortex (Norwegian University of Science and Technology 2014) (refer to Figure 1). The entorhinal cortex has not been studied as extensively as the hippocampus. A search for articles on the topic of the entorhinal region indexed in Web of Science showed that relatively little research was done in this area prior to the 1990s. What was known about the entorhinal cortex was that it has a role in providing sensory input to the hippocampus, has an important function in memory storage, and may play a role in some neurodegenerative diseases such as Alzheimer's (Levisohn and Isacson 1991). After a few years of not getting the response they were looking for from hippocampal lesions, the Mosers decided to look more closely at the entorhinal cortex and were able to record spikes in activity in the dorsocaudal medial entorhinal cortex (dMEC) of moving rats. Mathematical calculations of the recorded spikes in activity showed equilateral triangles between three cells, which in turn form perfect hexagonal patterns. These hexagonal patterns form a location grid, allowing for high precision in determining position and route (Hafting et al. 2005) (see Figure 3). The Mosers' research on the entorhinal cortex identified grid cells and showed that they work with the hippocampal place cells in navigation, awareness of space, and location memory. Grid cells have since been observed in bats and monkeys, and Jacobs et al. (2013) discussed the discovery of grid-like cells in humans.
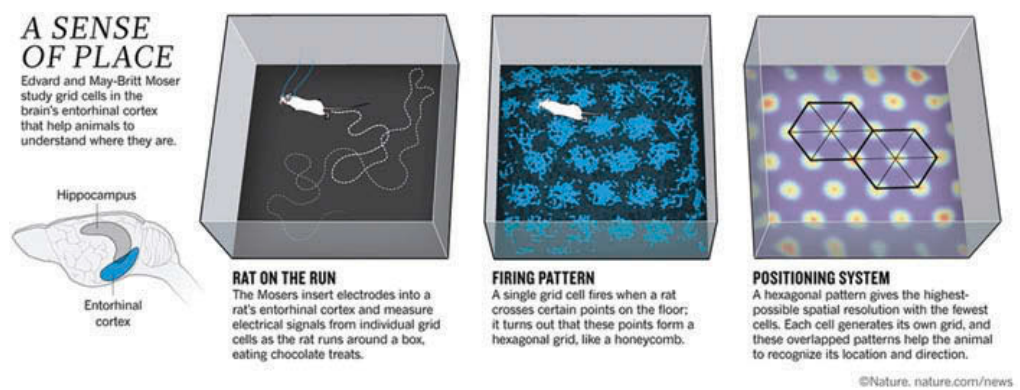

FIGURE 3 Electrodes inserted into a rat's entorhinal cortex show cells firing in a grid pattern. (Reprinted by permission from Macmillan Publishers Ltd: Nature “Neuroscience: Brains of Norway," copyright 2014.) 
The study of navigation and spatial orientation is often discussed in regards to two frames of reference. Allocentric refers to the relationship between objects, while egocentric refers to the relationship between an object, or objects, and the subject (Zaehle et al. 2007). The discoveries of place cells and grid cells lead scientists to believe that navigation is a combination of stimuli from the environment such as landmarks (allocentric map), as well as stimuli from the individual (egocentric map). Early studies such as Tolman's focused more on the idea of an egocentric map, but the discovery of place and grid cells show evidence of an allocentric map (Manning et al. 2014). Exactly how place cells in the hippocampus work with grid cells in the entorhinal cortex is still not entirely understood, and research continues (Azizi, Schieferstein, and Cheng 2014; Zhang et al. 2014).

The exact role of the hippocampal formation, the area of the brain that includes the hippocampus and the entorhinal cortex, is also still debated. It has been shown to affect memory and learning, perception, place learning, navigation, responsiveness to the environment (orienting reflex), and approach behavior (Eichenbaum, Otto, and Cohen 1992; Lee, Yeung, and Barense 2012; Vanderwolf 1969). It is also known that this part of the brain is affected early on in diseases such as Alzheimer's (Nobelprize.org 2014a). An early indication of Alzheimer's is memory impairment, including the loss of spatial memory. A recent study by Zhao et al. (2014) discussed hippocampal place cells altered by the buildup of amyloid proteins, such as what occurs with Alzheimer's disease, and the resulting functional decline in spatial information. The discoveries of the 2014 Physiology or Medicine Nobel Laureates have laid the framework for even more research into the brain, how humans navigate space, and brain disorders that affect memory. The scientific community owes a great deal to the discovery of place and grid cells.

\section{The Scientists}

\section{John O’Keefe}

\section{Life, Education, and Career}

John O'Keefe was born in New York City, in 1939 to Irish immigrant parents. He attended City College of New York (CCNY), where he received his BA in Psychology in 1963 (City College of New York 2014). It was in a physiology class at CCNY that O'Keefe met Eileen, his future wife. After earning his degree, O'Keefe traveled north to Montreal, Québec, where he attended McGill University, earning his MA (1964) and PhD (1967) in Physiological Psychology. He then decided to expand his education in yet another country, traveling to London, England, as a US National Institute of Mental Health postdoctoral fellow to train at University College London (UCL). O'Keefe, his wife, and their two children have remained in London, where O'Keefe was appointed Professor of Cognitive Neuroscience at UCL in 1987. O'Keefe also serves as the university's Inaugural Director of the new Sainsbury Welcome Centre for Neural Circuits and Behaviour (Gruber Foundation 2008).

From the beginning of his scientific studies O'Keefe has been interested in the brain and behavior. He has focused his research on the limbic system and medial temporal lobe, specifically the amygdala and hippocampus. While attending McGill University O'Keefe met Professor Brenda Milner, who ran the noted study on the patient $\mathrm{H}$. M. This study took place less than 10 years before O'Keefe began work on his doctorate, and it influenced him greatly. As a doctoral student, he studied how lesions on the hippocampus affect rodent behavior; the 1957 Milner and Scoville study convinced him that there was more to learn and, in part, resulted in his focus on the hippocampus (Sweet 2014). 
Throughout his long career O'Keefe has received many awards, including the Feldberg Foundation Prize in 2001, the Grawemeyer Award in Psychology with Lynn Nadel in 2006, the British Neuroscience Association Award for Outstanding Contribution to British Neuroscience in 2007, and both the Federation of European Neuroscience Societies European Neuroscience Journal Award and the Gruber Neuroscience Prize in 2008 (Gruber Foundation 2008). Less than a month before receiving the news about winning the 2014 Nobel, O'Keefe had traveled to Oslo, Norway, where he, Brenda Milner, and Marcus Raichle were awarded the Kavli Prize in neuroscience (Nobelprize.org 2014d). In addition to receiving many prestigious awards, O'Keefe has served as a chair of the British Neuroscience Association, was a Fellow of the Royal Society and the Academy of Medical Sciences, and served on numerous councils, including the Royal Society and the International Brain Research Organization. He received an honorary Doctorate of Science degree from University College Cork (UCC) on December 15, 2014 (University College Cork 2014). O'Keefe's father was born in Cork, Ireland, and his Irish heritage has been a point of pride in Ireland. Irish news sources have covered him and the news of the Nobel Prize thoroughly.

O'Keefe has given praise to those around him. He credits both CCNY for allowing him to get an education and to start his career and McGill University for the good fortune of earning his Masters under Donald Hebb's Psychology Department. During his interview with Adam Smith from nobelprize.org, O'Keefe stated "I think the Prize actually is as much for the field as for myself and the Mosers. I think, you know, we're just representatives of a large number of people who are working away at the hippocampus and memory and spatial navigation" (Nobelprize.org 2014d).

\section{Bibliometrics}

Since his pioneering 1971 article, John O'Keefe has published eighty-one articles that are indexed in Web of Science, the citation indexing service. The University College London Department of Cell \& Developmental Biology profile page includes articles that are not indexed in Web of Science, listing the number of O'Keefe's publications as 110 (Whitfield 2014). O'Keefe has published two articles a year for the past 43 years (see Figure 4).

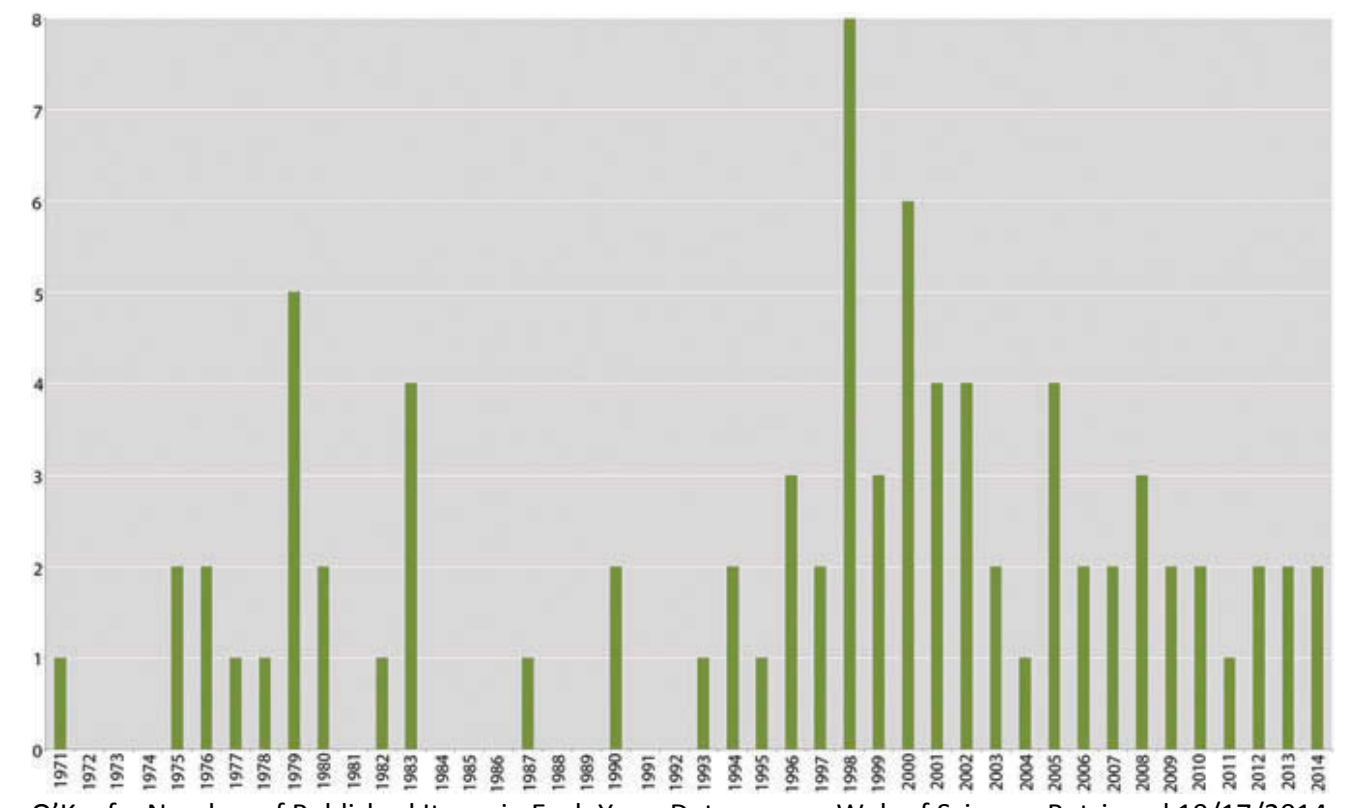

FIGURE 4 John O'Keefe, Number of Published Items in Each Year. Data source: Web of Science. Retrieved 10/17/2014. 
A review of O'Keefe's published research shows that his work was not initially widely acknowledged. It generally takes time for new scientists to grow their citation numbers, and this is the case for the first couple of decades of O'Keefe's career. Both the number of his publications and how often his work was cited have gradually increased over time. In 1996, his average number of citations per year doubled from 200 to 400. This increase in citations interestingly corresponds with the year that the Mosers visited O'Keefe to work with him in his lab. O'Keefe's citation count has continued to grow, and he is now cited approximately 1,000 times a year (see Figure 5). His research on the brain's role in navigation and spatial sense has become fundamental research. Web of Science calculates his h-index as 47, with an average of more than 190 citations per article published. After removing self-citations, O'Keefe has been cited around 15,000 times in nearly 9,000 articles. His 1971 article is now his second-most-highly cited article, averaging more than forty citations a year. All of O'Keefe's most frequently cited articles deal with place cells (see Table 1).

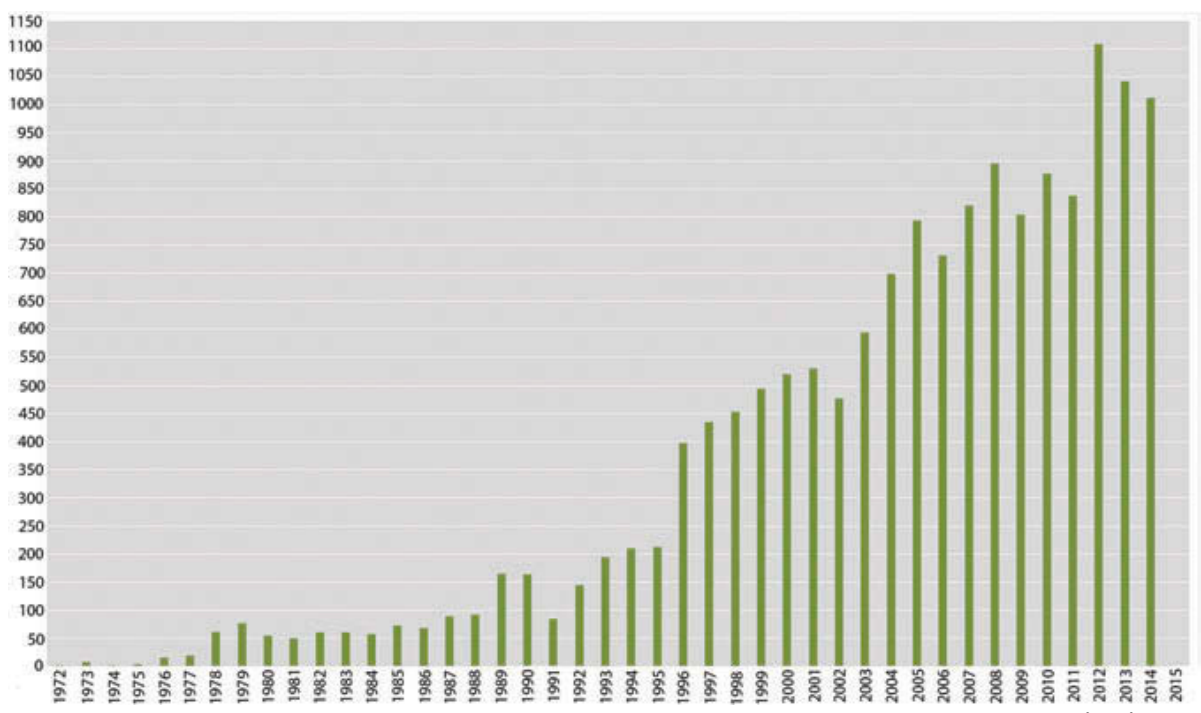

FIGURE 5 John O'Keefe, Number of Times Cited in Each Year. Data source: Web of Science. Retrieved 10/17/2014.

TABLE 1 Top Five Most Highly Cited Papers by John O'Keefe

\begin{tabular}{|l|l|l|}
\hline Number of times cited & Average number of citations per year & Citations \\
\hline 3548 & 107.5 & Morris et al. (1982) \\
\hline 1769 & 40.2 & O'Keefe and Dostrovsky (1971) \\
\hline 1022 & 46.5 & O'Keefe and Recce (1993) \\
\hline 648 & 16.6 & O'Keefe (1976) \\
\hline 641 & 49.3 & Burgess et al. (2002) \\
\hline
\end{tabular}

Data source: Web of Science. Retrieved October 17, 2014.

O'Keefe tends to publish in high-impact journals. The journal he has published in most frequently is Hippocampus, which has a 5-year impact factor of 5.059 and is ranked as number forty-nine of all the neuroscience journals summarized by Journal Citation Reports (JCR) as of 2014. O'Keefe publishes in both narrowly focused brain and neuroscience journals and broad multidisciplinary science journals such as Nature (see Table 2). He has also published books, including his influential and freely available The Hippocampus as a Cognitive Map, coauthored with Lynn Nadel. According to Google Scholar, this book has been cited almost 7,500 times since its publication in 1978. 
TABLE 2 Top Five Journals Published in by John O’Keefe

\begin{tabular}{|l|l|}
\hline Journal title & Number of articles \\
\hline Hippocampus & 14 \\
\hline Nature & 7 \\
\hline Journal of Neuroscience & 5 \\
\hline European Journal of Neuroscience & 5 \\
\hline All other journals have record counts of less than 5 & \\
\hline
\end{tabular}

\section{May-Britt Moser}

\section{Life, Education, and Career}

May-Britt (pronounced "My-Britt") Moser is one of only forty-six women Nobel Laureates, out of the 864 individuals who have won the Nobel Prize, and the eleventh woman to receive the Physiology or Medicine Nobel (Nobelprize.org 2014f). Moser was born in 1963 in Fosnavåg, Norway, on the western island of Bergs $\varnothing y$ y. After high school, May-Britt left the farm she grew up on to attend the University of Oslo (Bazilchuk 2014). Between 1982 and 1990 she earned degrees in mathematics, chemistry, physics, statistics, neurobiology, and psychology. She earned her PhD in neurophysiology in 1995. After defending her doctoral thesis, May-Britt and her husband Edvard worked under John O'Keefe in his laboratory for their postdoctoral work in 1996. Both May-Britt and Edvard then moved to Trondheim, Norway, where they began working at the Norwegian University of Science and Technology (NTNU) as Associate Professors of Biological Psychology (M.-B. Moser 2014).

In 2000, May-Britt became a Professor of Neuroscience, Faculty of Medicine at NTNU. Over the past 14 years she has taken on additional roles and earned numerous awards and honors. In 2007 she became the Founding Co-Director of the Kavli Institute for Systems Neuroscience, a position that she still holds. She was the Founding Co-Director of the Centre for the Biology of Memory for the life of the center (2002-2012) and became the Director of its replacement center, the Centre for Neural Computation (M.-B. Moser 2014). In addition to the positions at NTNU, May-Britt also serves as a member of the Royal Norwegian Society of Sciences and Letters, both the Norwegian Academies of Science and of Technological Sciences, the European Molecular Biology Organization, the European Dana Alliance for Brain Research, and Academia Europaea. From 2012 to 2014 she also served as a Programme Committee Member for the Federation of European Neuroscience Societies (FENS) Forum. An abbreviated list of awards she has won includes the Perl/UNC Neuroscience Prize from the University of North Carolina in 2013, the Louis-Jeantet Prize for Medicine from the Louis-Jeantet Foundation in 2011, the Betty and David Koetser Award for Brain Research from the University of Zürich in 2006, and the W. Alden Spencer Award from the College of Physicians and Surgeons of Columbia University in 2005 (Federation of European Neuroscience Societies n.d.).

May-Britt's interest and research passion is cognition, focusing on the sense of space. She continues to work with her husband and other colleagues on grid cells, their circuit, and how they work with the hippocampus on memory (M.-B. Moser 2014). Similar to O'Keefe, May-Britt expressed how the award was not just for the three of them. In her interview with nobelprize.org she said the award is as much for all those who supported them and everyone in their laboratory as it is for herself, her husband, and O'Keefe (Nobelprize.org 2014e). In other interviews she has expressed admiration for her research subjects, the rats, saying "if we wouldn't have the rats, and they would not like to collaborate with us, we would have no data . 
... If they are not happy, if they are not well, they are not going to give us good data" (Körber Foundation 2014).

\section{Bibliometrics}

May-Britt's bibliography is extensive, with eighty-one publications indexed in Web of Science since 1988, averaging more than three articles per year (see Figure 6). She has an h-index of 44 and, correcting for selfcitations, she has been cited almost 8,700 times in almost 4,600 articles. The impact of her research can be partially inferred through the steady increase in her citation counts (see Figure 7).

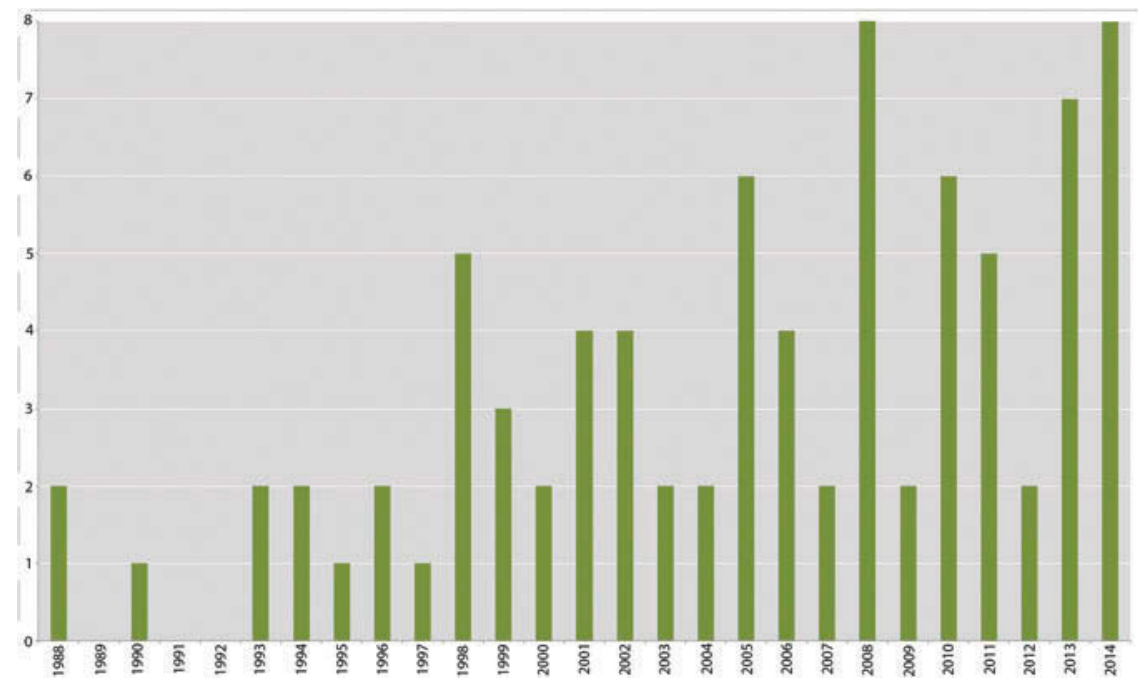

FIGURE 6 May-Britt Moser, Number of Published Items in Each Year. Data source: Web of Science. Retrieved 11/13/2014.

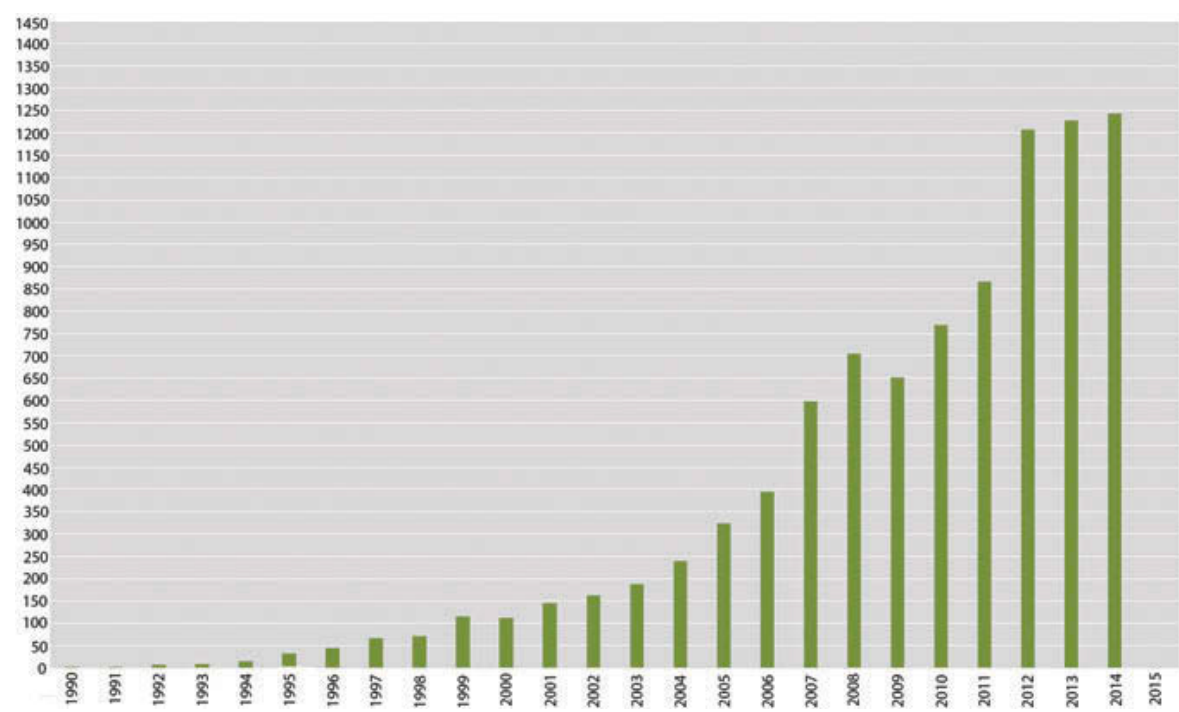

FIGURE 7 May-Britt Moser, Number of Times Cited in Each Year. Data source: Web of Science. Retrieved 11/13/2014.

It makes sense that May-Britt's most highly cited article, with almost 750 citations, is the 2005 publication on the discovery of grid cells. Her other most-cited articles have approximately 400-500 citations each (see Table 3). Similar to her mentor O'Keefe, Moser's publications are in both high-impact neuroscience and high-impact multidisciplinary sciences journals (see Table 4). Thirteen of her eighty-one publications are in the journal Neuron, which has a 5-year impact factor of 16.485 and is ranked fifth among neuroscience journals. 
TABLE 3 Top Five Most Highly Cited Papers by May-Britt Moser

\begin{tabular}{|l|l|l|}
\hline Number of times cited & Average number of citations per year & Citation \\
\hline 748 & 74.8 & Hafting et al. (2005) \\
\hline 520 & 30.6 & Moser and Moser (1998) \\
\hline 492 & 22.4 & Moser, Moser, and Andersen (1993) \\
\hline 464 & 51.6 & McNaughton et al. (2006) \\
\hline 405 & 50.6 & Leutgeb et al. (2007) \\
\hline
\end{tabular}

Data source: Web of Science. Retrieved November 13, 2014.

TABLE 4 Top Five Journals Published in by May-Britt Moser

\begin{tabular}{|l|l|}
\hline Journal title & Number of articles \\
\hline Neuron & 13 \\
\hline Science & 11 \\
\hline Nature & 8 \\
\hline Journal of Neuroscience & 7 \\
\hline Hippocampus & 6 \\
\hline
\end{tabular}

Data source: Web of Science. Retrieved November 13, 2014.

\section{Edvard I. Moser}

\section{Life, Education, and Career}

Edvard Ingjald Moser was born in 1962 to German immigrant parents on an island just north of his future wife in Ålesund, Norway. Moser attended the University of Oslo where he began earning his multitude of degrees in 1984. He has degrees in mathematics, statistics, programming, neurobiology, and psychology. Edvard earned his PhD in physiology in 1995 and did his postdoctoral research in 1996 with May-Britt in John O'Keefe's lab in London. After leaving London, Edvard became an Associate Professor of Biological Psychology at NTNU in Trondheim, Norway. He and his wife were able to negotiate for both of their Associate Professorships at NTNU, but they had to build their lab from scratch in an old bomb shelter (Bazilchuk 2014). In 1998 Edvard became a Professor of Biological Psychology/Neuroscience in the Department of Psychology. From 2002 to 2012 he served as Founding Co-Director of the Centre for the Biology of Memory. He currently serves as Founding Director of the Kavli Institute for Systems Neuroscience and the Co-Director of the Centre for Neural Computation (E. I. Moser 2014).

Similar to his fellow Nobel winners, Edvard has earned many awards throughout his career. Examples include: the Karl Spencer Lashley Award from the American Philosophical Society in 2014, the Louis-Jeantet Prize for Medicine from the Louis-Jeantet Foundation in 2011, the W. Alden Spencer Award from College of Physicians and Surgeons of Columbia University in 2005, and the 1999 Prize for young scientists awarded by the Royal Norwegian Academy for Sciences and Letters. He has been a member of the Royal Norwegian Society of Sciences and Letters since 2003 and a member of the Norwegian Academy of Science and Letters since 2004. He also served as Past Chair Programme Committee of the Federation of European Neuroscience Societies (FENS) from 2004 to 2006. Other memberships include those in The Norwegian Academy of Technological Sciences, the European Molecular Biology Organization, the European Dana Alliance for Brain 
Research, and Academia Europaea. He served as Councilor for the Society for Neuroscience and was a Fellow of the American Association for the Advancement of Science (E. I. Moser 2014).

Edvard shares the interests of his wife, May-Britt, and mentor John O'Keefe. He is interested in how the brain figures out where we are in space and how we remember that space. His research with May-Britt continues the study of the entorhinal cortex and organization and formation of grid cells (E. I. Moser 2014). Like his wife and O'Keefe, Edvard expressed gratitude and praise for those around him. In Edvard's interview with nobelprize.org, his words were almost verbatim those of his wife and O'Keefe-even though he had not yet had a chance to speak to either of them. He views their discoveries as being a result of teamwork with a lot of people "who are completely invisible" (Nobelprize.org 2014c).

\section{Bibliometrics}

Edvard Moser's bibliography is another impressive example of research and publication. He has 112 publications indexed in Web of Science, averaging four articles published each year since 1986 (see Figure 8). His articles are highly cited, with almost 9,500 total citations, not including self-citations, in nearly 5,000 articles. This gives him a strong h-index of 51 and an average of almost ninety-one citations per article published. Most of these citations occurred after his influential 2005 article (see Figure 9).

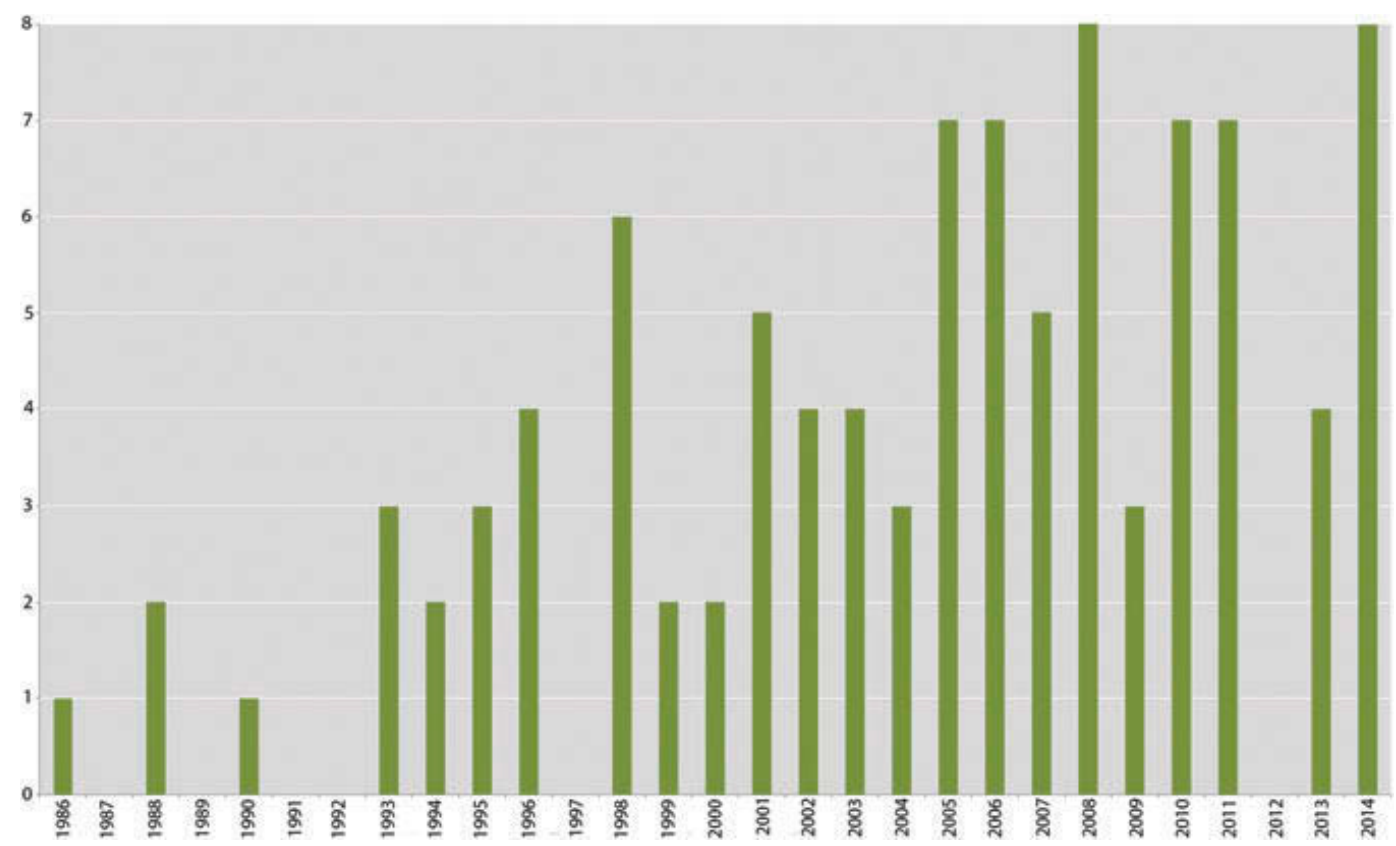

FIGURE 8 Edvard Moser, Number of Published Items in Each Year. Data source: Web of Science. Retrieved 11/13/2014. 


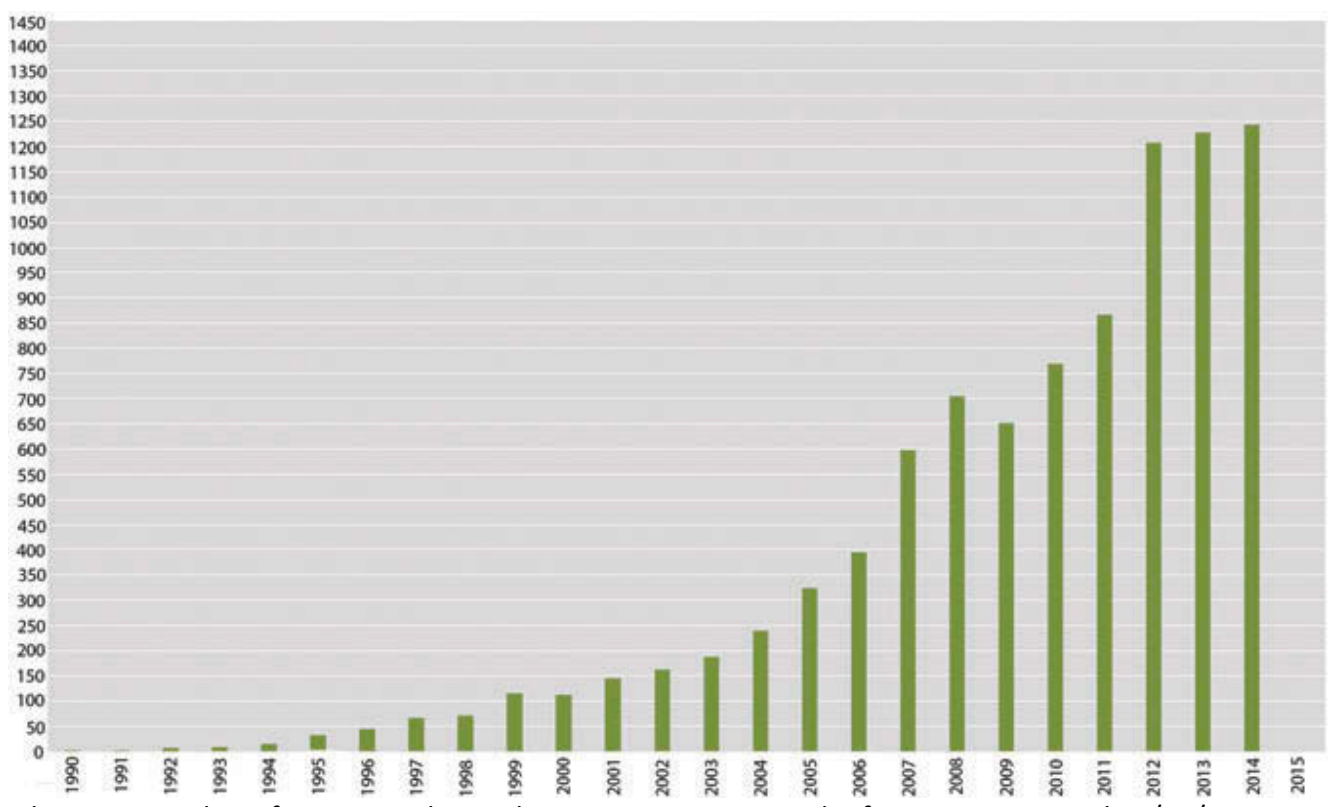

FIGURE 9 Edvard Moser, Number of Times Cited in Each Year. Data source: Web of Science. Retrieved 11/13/2014.

Not surprisingly, Edvard's publications match those of his wife, and longtime collaborator, May-Britt. They have worked, researched, and written together for their entire careers. His most-highly cited articles are the same as those of May-Britt (see Table 5). The same is true for the journals in which Edvard has published. His top five journals are the same high-impact journals as May-Britt, although his publication numbers are slightly higher (see Table 6).

TABLE 5 Top Five Most Highly Cited Papers by Edvard Moser

\begin{tabular}{|l|l|l|}
\hline Number of times cited & Average number of citations per year & Citation \\
\hline 748 & 74.8 & Hafting et al. (2005) \\
\hline 520 & 30.6 & Moser and Moser (1998) \\
\hline 492 & 22.4 & Moser et al. (1993) \\
\hline 464 & 51.6 & McNaughton et al. (2006) \\
\hline 405 & 50.6 & Leutgeb et al. (2007) \\
\hline
\end{tabular}

Data source: Web of Science. Retrieved November 13, 2014.

TABLE 6 Top Five Journals Published in by Edvard Moser

\begin{tabular}{|l|l|}
\hline Journal title & Number of articles \\
\hline Neuron & 13 \\
\hline Science & 12 \\
\hline Nature & 10 \\
\hline Journal of Neuroscience & 10 \\
\hline Hippocampus & 9 \\
\hline
\end{tabular}

Data source: Web of Science. Retrieved November 13, 2014. 


\section{The Mosers}

It is hard to miss the overlap of the Mosers' lives and careers. They have known each other since high school and worked side by side since their undergraduate days at Oslo. The couple shares everything. They work on the same research, run the same organizations, supervise the same postdoctoral and PhD students, win the same awards, serve on the same committees, and have jointly raised their two daughters. As for winning the Nobel, they are the fourth married couple to win it in the sciences, and the fifth pair to win any Nobel. Gerty and Carl Cori were the first couple to win the Physiology or Medicine Prize in 1947, and the Mosers are the second. They are also the first scientists in Norway to win the Medicine Nobel (Nobelprize.org 2014g).

Looking at their publications, it is evident that since 1988, if not earlier, their interests have both been on exploratory behavior and spatial learning in rats. John O'Keefe knew that his mentees were going to do extraordinary work together and says that they put what they learned in his lab "to very good use" (Nobelprize.org 2014d). They built their first lab together when it was just the two of them. As their lab grew and they started winning grants, both together and individually, they improved the lab. Eventually the influence and importance of their work allowed them to turn their Centre for the Biology of Memory (CBM) into the Kavli Institute for Systems Neuroscience and the Centre for Neural Computation (KI/CNC). In 2005, after the discovery of grid cells, Fred Kavli and the president of the Kavli Institute, David Auston, visited the CBM. In 2007 it became one of only four Kavli Foundation recognized neuroscience institutes in the world. Due to the success of the CBM, the Norwegian Research Council extended funding beyond the initial 10 years, turning the CBM into the CNC. The Mosers run the organization together, with Edvard serving as Director of the Kalvi Institute and May-Britt serving as Director of the Centre for Neural Computation (Norwegian University of Science and Technology n.d.).

\section{Conclusion}

The 2014 Nobel Prize in Physiology or Medicine was awarded to three exceptional scientists "for their discoveries of cells that constitute a positioning system in the brain" (Nobelprize.org 2014b). John O'Keefe made the groundbreaking discovery of hippocampal place cells in 1971, and May-Britt and Edvard Moser built upon his work, discovering grid cells in the entorhinal cortex in 2005. The married couple worked with O'Keefe, learned from him, and continue to think of him as a mentor. The work of these three scientists has led to a better understanding of the brain, memory, and sense of space and navigation. This understanding and increased knowledge of the hippocampal formation, including the entorhinal cortex, can lead to research that will provide a better understanding of higher cognitive functions and of diseases such as Alzheimer's.

\section{References}

Azizi, A. H., N. Schieferstein, and S. Cheng. 2014. The transformation from grid cells to place cells is robust to noise in the grid pattern. Hippocampus 24 (8): 912-19. doi:10.1002/hipo.22306.

Bazilchuk, N. 2014. From bomb shelter beginnings to the Nobel Prize. Gemini. http://gemini.no/en/2014/10/from-bomb-shelter-beginnings-to-the-nobel-prize/ (accessed November 14, 2014). 
Burgess, N., E. A. Maguire, and J. O'Keefe. 2002. The human hippocampus and spatial and episodic memory. Neuron 35 (4): 625-41. doi:10.1016/s0896-6273(02)00830-9.

City College of New York. 2014. Harlem native John O’Keefe credits CCNY for Nobel Prize. http://www.ccny.cuny.edu/news/okeefe-interview.cfm (accessed October 20, 2014).

Eichenbaum, H., T. Otto, and N. J. Cohen. 1992. The hippocampus-What does it do? Behavioral and Neural Biology 57 (1): 2-36. doi:10.1016/0163-1047(92)90724-i.

Ekstrom, A. D., M. J. Kahana, J. B. Caplan, T. A. Fields, E. A. Isham, E. L. Newman, and I. Fried. 2003. Cellular networks underlying human spatial navigation. Nature 425 (6954): 184-88. doi:10.1038/nature01964.

Federation of European Neuroscience Societies. n.d. Moser, May-Britt. http://www.fens.org/People/MoserMay-Britt/ (accessed October 20, 2014).

Gruber Foundation. 2008. 2008 Neuroscience Prize: John O'Keefe. http://gruber.yale.edu/neuroscience/john-okeefe (accessed October 20, 2014).

Hafting, T., M. Fyhn, S. Molden, M.-B. Moser, and E. I. Moser. 2005. Microstructure of a spatial map in the entorhinal cortex. Nature 436 (7052): 801-06. doi:10.1038/nature03721.

Jacobs, J., C. T. Weidemann, J. F. Miller, A. Solway, J. F. Burke, X.-X. Wei, N. Suthana, M. R. Sperling, A. D. Sharan, I. Fried, and M. J. Kahana. 2013. Direct recordings of grid-like neuronal activity in human spatial navigation. Nature Neuroscience 16 (9): 1188-90. doi:10.1038/nn.3466.

Körber Foundation. 2014. May-Britt and Edvard Moser-Winner of the Körber European Science Prize 2014. http://www.koerber-stiftung.de/mediathek/player/may-britt-and-edvard-moser-winner-of-thekoerber-european-scienceprize-2014.html (accessed November 2, 2014).

Lee, A. C. H., L.-K. Yeung, and M. D. Barense. 2012. The hippocampus and visual perception. Frontiers in Human Neuroscience 6. doi:10.3389/fnhum.2012.00091.

Leutgeb, J. K., S. Leutgeb, M.-B. Moser, and E. I. Moser. 2007. Pattern separation in the dentate gyrus and CA3 of the hippocampus. Science 315 (5814): 961-66. doi:10.1126/science.1135801.

Levisohn, L. F., and O. Isacson. 1991. Excitotoxic lesions of the rat entorhinal cortex: Effects of selective neuronal damage on acquisition and retention of a non-spatial reference memory task. Brain Research 564 (2): 230-44. doi:10.1016/0006-8993(91)91458-d.

Manning, J. R., T. F. Lew, L. Ningcheng, R. Sekuler, and M. J. Kahana. 2014. MAGELLAN: A cognitive mapbased model of human wayfinding. Journal of Experimental Psychology: General 143 (3): 1314-30. doi:10.1037/a0035542.

McNaughton, B. L., F. P. Battaglia, O. Jensen, E. I. Moser, and M.-B. Moser. 2006. Path integration and the neural basis of the "cognitive map." Nature Reviews Neuroscience 7 (8): 663-78. doi:10.1038/nrn1932.

Morris, R. G. M., P. Garrud, J. N. P. Rawlins, and J. O'Keefe. 1982. Place navigation impaired in rats with hippocampal lesions. Nature 297 (5868): 681-83. doi:10.1038/297681a0. 
Moser, E., M. B. Moser, and P. Andersen. 1993. Spatial-learning impairment parallels the magnitude of dorsal hippocampal lesions, but is hardly present following ventral lesions. Journal of Neuroscience 13 (9): 3916-25.

Moser, E. I. 2014. Curriculum vitae: Edvard I. Moser. http://www.aeinfo.org/attach/User/Moser Edvard/CV/CV Edvard-Moser.pdf (accessed November 14, 2014).

- - . 2014. Curriculum vitae: May-Britt Moser. http://www.ae-info.org/attach/User/Moser_MayBritt/CV/CV_May-Britt-Moser.pdf (accessed November 14, 2014).

Moser, M.-B., and E. I. Moser. 1998. Functional differentiation in the hippocampus. Hippocampus 8 (6): 60819. doi:10.1002/(sici)1098-1063(1998)8:6<608::aid-hipo3>3.0.co;2-7. Nobelprize.org. 2014a. The 2014 Nobel Prize in Physiology or Medicine-Advanced information. http://www.nobelprize.org/nobel prizes/medicine/laureates/2014/advanced.html (accessed October 20, 2014).

- - . 2014b. The 2014 Nobel Prize in Physiology or Medicine-Press release. http://www.nobelprize.org/nobel prizes/medicine/laureates/2014/press.html (accessed November 11, 2014).

- - - 2014c. Interview with Edvard I. Moser. http://www.nobelprize.org/nobel prizes/medicine/laureates/2014/edvard-moser-telephone.html (accessed October 10, 2014).

- - . 2014d. John O’Keefe-Interview. http://www.nobelprize.org/nobel prizes/medicine/laureates/2014/okeefe-interview.html (accessed October 10, 2014).

-- - 2014e. May-Britt Moser-Interview. http://www.nobelprize.org/nobel prizes/medicine/laureates/2014/may-britt-moser-interview.html (accessed October 10, 2014).

- - . 2014f. Nobel Prize awarded women. http://www.nobelprize.org/nobel prizes/lists/women.html (accessed October 20, 2014).

- - . 2014g. Nobel Prize facts. http://www.nobelprize.org/nobel prizes/facts/ (accessed October 10, 2014).

- - . 2014h. Nomination and selection of medicine laureates. http://www.nobelprize.org/nomination/medicine/ (accessed October 20, 2014). Norwegian University of Science and Technology. n.d. About Kavli Institute for Systems Neuroscience Centre for Neural Computation. http://www.ntnu.edu/kavli/about (accessed October 20, 2014).

- - . 2014. 2014 Nobel Prize Winners-A journey into entorhinal cortex. http://www.ntnu.edu/nobelprize2014/videos (accessed November 2, 2014).

O'Keefe, J. 1976. Place units in the hippocampus of the freely moving rat. Experimental Neurology 51 (1): 78-109. doi:10.1016/0014-4886(76)90055-8. 
O'Keefe, J., and J. Dostrovsky. 1971. The hippocampus as a spatial map: Preliminary evidence from unit activity in the freely-moving rat. Brain Research 34 (1): 171-75. doi:10.1016/0006-8993(71)90358-1.

O'Keefe, J., L. Nadel, S. Keightley, and D. Kill. 1975. Fornix lesions selectively abolish place learning in the rat. Experimental Neurology 48 (1): 152-66. doi:10.1016/0014-4886(75)90230-7.

O'Keefe, J., and M. L. Recce. 1993. Phase relationship between hippocampal place units and the EEG theta rhythm. Hippocampus 3 (3): 317-30. doi:10.1002/hipo.450030307.

Scoville, W. B., and B. Milner. 1957. Loss of recent memory after bilateral hippocampal lesions. Journal of Neurology Neurosurgery and Psychiatry 20 (1): 11-21. doi:10.1136/jnnp.20.1.11.

Squire, L. R., and S. Zola-Morgan. 1991. The medial temporal lobe memory system. Science 253 (5026): 1380-86. doi:10.1126/science.1896849.

Sweet, D. 2014. Nobel winner has very fond memories of McGill. http://publications.mcgill.ca/reporter/2014/10/nobel-winner-has-very-fond-memories-of-mcgill/ (accessed October 20, 2014).

Tolman, E. C. 1948. Cognitive maps in rats and men. Psychological Review 55 (4): 189-208. doi:10.1037/h0061626 University College Cork. 2014. Honorary doctorate for Nobel Laureate Professor John O'Keefe. http://www.ucc.ie/en/news/fullstory-512514-en.html (accessed December 8, 2014).

Vanderwolf, C. H. 1969. Hippocampal electrical activity and voluntary movement in the rat. Electroencephalography and Clinical Neurophysiology 26 (4): 407-18. doi:10.1016/00134694(69)90092-3.

Walther, C. 2002. Hippocampal terminology: Concepts, misconceptions, origins. Endeavour 26 (2): 41-44. doi:10.1016/S0160-9327(02)01412-6.

Whitfield, E. 2014. The O'Keefe and Burgess Groups. http://www.ucl.ac.uk/cdb/research/okeefe (accessed September 26, 2014).

Zaehle, T., K. Jordan, T. Wüstenberg, J. Baudewig, P. Dechent, and F. W. Mast. 2007. The neural basis of the egocentric and allocentric spatial frame of reference. Brain Research 1137: 92-103. doi:10.1016/j.brainres.2006.12.044.

Zhang, S., F. Schonfeld, L. Wiskott, and M.-V. Denise. 2014. Spatial representations of place cells in darkness are supported by path integration and border information. Frontiers in Behavioral Neuroscience 8. doi:10.3389/fnbeh.2014.00222

Zhao, R., S. W. Fowler, A. C. A. Chiang, D. Ji, and J. L. Jankowsky. 2014. Impairments in experience-dependent scaling and stability of hippocampal place fields limit spatial learning in a mouse model of Alzheimer's disease. Hippocampus 24 (8): 963-78. doi:10.1002/hipo.22283. 